\title{
A prática docente do professor de língua materna sobre a competência comunicativa junto aos alunos da segunda fase do Ensino Fundamental II.
}

(The teaching practice of the mother tongue teacher on communicative competence among the students of the second phase of Elementary School II.)

\author{
Angélica D. Medeiros Junqueira \\ Escola Municipal Guiomar de Campos Miranda
}

Fecha recepción: 01-10-2017

Páginas 61-76

Fecha aceptación: 01-12-2017

\section{Resumo.}

A pesquisa de doutorado buscou averiguar como se desenvolve a competência comunicativa e sua relação com a prática pedagógica em língua portuguesa e se a prática docente em língua materna desenvolve a competência comunicativa nos alunos. Assim sendo, analisou a prática docente do professor de língua materna em relação a aquisição da competência comunicativa na Escola Agrícola Municipal "Dep. Hitler Sansão, sendo 149 alunos do $5^{\mathrm{a}}$ ao $9^{\circ}$ ano matutino e professores de língua portuguesa. Quanto a abordagem da pesquisa quali quantitativa, do tipo descritiva, a qual traduziu em números as informações coletadas, utilizou-se para a coleta de dados, questionário fechado e entrevista semiestruturada com os professores. Assim sendo, a prática docente ainda não desenvolve a competência comunicativa, pois, a mesma está voltada para a gramática normativa, ainda, apresentam dificuldades de passar os conteúdos de maneira contextualizada.

Palavras Chaves: prática; comunicação; competência; professores; alunos

\section{Abstract.}

The doctoral research sought to investigate how the communicative competence and its relation with the pedagogical practice in Portuguese language is developed and if the teaching practice in the mother tongue develops the communicative competence in the students. Thus, it analyzed the teaching practice of the mother tongue teacher in relation to the acquisition of communicative competence in the Municipal Agricultural School "Dep. Hitler Sansão, with 149 students from the 5th to the 9th grade and teachers of the Portuguese language. As for the quantitative qualitative research approach, of the descriptive type, which translated the information collected into numbers, it was used for data collection, closed questionnaire and semistructured interview with the teachers. Thus, the teaching practice still does not develop the communicative competence, because it is focused on normative grammar, yet, they present difficulties to pass the contents in a contextualized way.

Keywords: practice; Communication; competence; teachers; students 


\section{1.-Introdução.}

As mudanças ocorridas na área da educação demonstram um novo conceito de educação, de educador e de educando, assim destacamos os Parâmetros Curriculares Nacionais, que é um dos documentos oficiais brasileiro voltado para 0 desenvolvimento da educação brasileira, este inclui a interdisciplinaridade, as inteligências múltiplas, a ludicidade, a contextualização, a transdisciplinar idade, os distúrbios de aprendizagem, a informática, o qual inovam a educação democrática no âmbito nacional. Os Parâmetros Curriculares de Língua Portuguesa do ensino fundamental II oferece uma variedade de metodologias inovadoras, para desenvolver a competência comunicativa de forma dosada no aluno, dando um caráter de continuidade que, necessariamente, deva nortear todo e qualquer processo educativo.

Este artigo trouxe uma temática relevante, pois, esta poderá contribuir para que 0 professor possa rever seus conceitos e objetivos como educador que visa 0 aprendizado do aluno. E após leitura de vários teóricos e as reflexões sobre a prática pedagógica dos professores de língua portuguesa, foi decidido realizar uma investigação sobre o tema, partindo da seguinte pergunta: A prática docente do professor de Língua Materna contribui para desenvolver a competência comunicativa nos alunos da segunda fase do ensino fundamental II?", a partir do mesmo se menciona o Objetivo Especifico da investigação que é Analisar a prática docente do professor de Língua Materna em relação a aquisição da competência comunicativa nos alunos da segunda fase do ensino fundamental II. Assim a pesquisa será realizada no período matutino da Escola Municipal Agrícola de $1^{\circ}$ grau Dep. Hitler Sansão, situada no município de Barra do Bugres, Mato Grosso, Brasil.

A problematização se deu pela falta de aquisição de competência comunicativa para o êxito no processo de ensino e aprendizagem no ensino fundamental II. O professor não é mais a figura central, exige-se mais experiente para ensinar e aprende proporcionando ao educando aprender da maneira mais fácil possível. Remete-nos a compreender que as metodologias oferecidas ao aluno, devem ser mais exploradas, numa relação de interação para com a aprendizagem. Assim Charolles (1989), declara que todo falante possui três capacidades textuais básicas: capacidade formativa; capacidade transformativa; capacidade qualificativa. Para Fávero \& Koch (1983), se todos os usuários da língua possuem essas habilidades, podem ser nomeadas genericamente como competência comunicativa, podendo justificar-se, então, a elaboração de uma gramática textual.

Com isso a inquietação: A prática docente do professor de Língua Materna contribui para desenvolver a competência comunicativa nos alunos da segunda fase do ensino fundamental II?" Objetivo geral: Analisar a prática docente do professor de Língua Materna em relação à aquisição da competência comunicativa na Escola agrícola Municipal "Dep. Hitler Sansão". 
Objetivos específicos: Identificar a prática que o professor de Língua Portuguesa adota no processo ensino aprendizagem; Verificar o quanto os alunos pesquisados consideram importante 0 ensino da gramática normativa; Evidenciar o grau de dificuldade que os alunos tem em relação aos conteúdos programáticos da disciplina de língua portuguesa.

O não considerar a realidade do aluno e o seu processo histórico social é apenas repassar conteúdos linguísticos que não são vinculados ao seu cotidiano, não contextualizando significativamente a aprendizagem do aluno, não suprirá a necessidade do aluno em aprender e desenvolver a competência comunicativa tão esperada e desejada no atual modelo educacional brasileiro, partindo dessa reflexão estaremos estudando a prática do professor de língua materna sob esta perspectiva.

\section{2.-Competência comunicativa.}

O termo competência comunicativa foi cunhado por Hymes no contexto da aquisição de língua materna e da Etnografia da Fala, apresenta a competência comunicativa como "varios sistemas de reglas que se refleja en los juicios y capacidades de aquéllos cuyos mensajes manifiesta el comportamiento" Hymes (1995, p. 37). Santos Gargallo (1999), colocam que tal conceito foi adaptado para o ensino de línguas estrangeiras já nos anos 70, sendo reformulado várias vezes, e em 1983 o conceito de Canale foi aceito de maneira geral Santos Gargallo (1999, p. 31).

A aplicação do conceito de competência comunicativa ao ensino de línguas no início dos anos 70 significou uma mudança de orientação no ensino, pois ele aborda o estudo da língua em uso e não como sistema descontextualizado; até esse momento havia prevalecido o estruturalismo, um modelo que entendia a língua como sistema hierarquizado de estruturas linguísticas, e o condutismo psicológico com a sua visão de aprendizagem como resultado do binômio estímulo-resposta, Santos Gargallo (1999, p. 31).

Segundo Faraco (1992) em seu livro "Prática de Texto" diz que a competência Linguística está em todas as nossas atividades, nós vivemos entrelaçados pelas palavras, estabelecem todas as nossas relações e nossos limites, dizem quem somos, quem são os outros, onde estamos, o que vamos fazer e o que fizemos. Nossos sonhos são povoados de palavras; todas as nossas emoções e sentimentos se revestem de palavras. É pela linguagem, afinal, que somos indivíduos únicos: somos o que somos depois de um processo de conquista da nossa palavra.

Portanto, a competência comunicativa ocorre de maneira espontânea, apesar dessa evidência ainda sabemos pouco sobre a linguagem, e em geral temos uma relação problemática com ela. Portanto a competência comunicativa se dá através do desenvolvimento da aquisição da fala, e é em nosso dia-dia que aprimoramos essa competência. 
Entretanto esse desenvolvimento se dá através de uma aprendizagem contextualizada, veiculada à pratica, e portanto não pode ser tratada somente como conhecimento teórico e ser simplesmente transmitido aos alunos sem contextualização. É necessário desenvolver estratégicas formativas que permitam a reflexão fundamentada sobre a aquisição dessa habilidade.

\section{1.-Leitura.}

De acordo com Fisher (2006), em seu livro "História da Leitura" fala que a leitura surgiu quando o Homem Neandertal e os Homo Sapiens, liam entalhes em ossos sinalizando algo que tinha significado para eles. Fala também que os filósofos Aristóteles, Sócrates e Platão foram uns dos primeiros a fazerem estudo sobre a leitura e a escrita, pois para eles a leitura e a escrita não existiam como propriedade autônoma.

0 processo ensino aprendizagem tem 0 aluno como tema central, pois ele é o ser que aprende e estabelece sua relação com 0 objeto de aprendizagem - a língua. Antes mesmo da criança saber ler digo como as pessoas já alfabetizadas, ela já observa, pensa e vai adquirindo conceitos interiorizados a respeito da língua (símbolos linguísticos), esses conceitos serão essencial para desenvolver a consciência social da leitura.

0 ato de ler ativa uma série de ações na mente do leitor pelas quais ele extrai informações, elas ocorrem despercebidas, elas ocorrem simultaneamente. Ao ler um texto qualquer, a mente seleciona o que lhe interessa do conteúdo, apenas presta atenção aos aspectos que the interessa, sem os quais não poderiam entender 0 enunciado. Assim através da observação a criança já conceitua quantidade e apresentam letras variadas e sons diferentes.

Acreditando no ensino baseado na interação comunicativa, de acordo com Travaglia (1997, p.151): As atividades que o professor desenvolver, devem sempre fazer o aluno pensar na razão de se usar determinado recurso em determinada situação para produzir determinado efeito de sentido. Isto vai fazer com que ele utilize com mais segurança e precisão os recursos da língua ao produzir seus textos e tenha capacidade de leitura bastante ampliada e aperfeiçoada.

Partindo desse pressuposto, percebemos que a criança adquiri vários meios para se apropriar da leitura à medida que interage com o meio em que vive, especialmente quando observa 0 adulto lendo diversos textos. $\mathrm{Na}$ aprendizagem da leitura a criança tem como referência o mundo que a cerca porque aprendem pensando, estabelecendo relações sobre às característica da linguagem ao seu ambiente familiar ou escolar. É necessário portanto, que o professor proporcione condição para que a criança possa apropriar-se desse meio de informação e comunicação que é a leitura. 


\section{2.-Escrita.}

De acordo Almeida (1994) a história da escrita surgiu na Pré-História quando o homem buscou se comunicar através de desenhos feitos nas paredes das cavernas. Através deste tipo de representação (pintura rupestre), trocavam mensagens, passavam idéias e transmitiam desejos e necessidades. Porém, ainda não era um tipo de escrita, pois não havia organização, nem mesmo padronização das representações gráficas. Foi somente na antiga Mesopotâmia que a escrita foi elaborada e criada. Por volta de 4000 a.C, os sumérios desenvolveram a escrita cuneiforme. Usavam placas de barro, onde cunhavam está escrita. Muito do que sabemos hoje sobre este período da história, devemos as placas de argila com registros cotidianos, administrativos, econômicos e políticos da época.

Os egípcios antigos também desenvolveram a escrita quase na mesma época que os sumérios. Existiam duas formas de escrita no Antigo Egito: a demótica (mais simplificada) e a hieroglífica (mais complexa e formada por desenhos e símbolos). As paredes internas das pirâmides eram repletas de textos que falavam sobre a vida dos faraós, rezas e mensagens para espantar possíveis saqueadores. Uma espécie de papel chamada papiro, que era produzida a partir de uma planta de mesmo nome, também era utilizado para escrever. Já em Roma Antiga, no alfabeto romano havia somente letras maiúsculas. Contudo, na época em que estas começaram a ser escritas nos pergaminhos, com auxílio de hastes de bambu ou penas de patos e outras aves, ocorreu uma modificação em sua forma original e, posteriormente, criouse um novo estilo de escrita denominado uncial. 0 novo estilo resistiu até o século VIII e foi utilizado na escritura de Bíblias lindamente escritas. Na Alta Idade Média, no século VIII, Alcuíno, um monge inglês, elaborou outro estilo de alfabeto atendendo ao pedido do imperador Carlos Magno.

Contudo, este novo estilo também possuía letras maiúsculas e minúsculas. Com 0 passar do tempo, esta forma de escrita também passou por modificações, tornandose complexa para leitura. Contudo, no século XV, alguns eruditos italianos, incomodados com este estilo complexo, criaram um novo estilo de escrita. No ano de 1522, um outro italiano, chamado Lodovico Arrighi, foi o responsável pela publicação do primeiro caderno de caligrafia. Foi ele quem deu origem ao estilo que hoje denominamos itálico. Com o passar do tempo outros cadernos também foram impressos, tendo seus tipos gravados em chapas de cobre (calcografia). Foi deste processo que se originou a designação de escrita calcográfica.

\section{3.-Linguagem oral.}

Segundo Almeida (1994)," A língua é produzida socialmente. Sua produção é fato cotidiano, localizado no tempo e no espaço da vida dos homens: uma questão dentro da vida e da morte, do prazer e do sofrer." A comunicação pela fala muitas vezes acontece improvisações, Possenti (1997) O discurso da composição literária, ficcional, científica ou realista, permitindo maior intimidade com as possibilidades subjetivas de elaboração ou dramatização da realidade. Tudo começa com a fala e 0 
exemplo. Com a competência comunicativa do discurso docente. 0 discurso é a linguagem em ação. A língua assumida pelo falante. Uma unidade de comunicação superior à frase. Uma sequência na maior parte das vezes longa, o discurso é sinônimo de enunciado do ponto de vista linguístico. A oposição enunciado/discurso serve para marcar o suposto antagonismo entre linguístico e não-linguístico. A linguística opera sobre os enunciados que, reagrupados em corpus (conjunto de enunciados), se apresentavam à variedade de análise da língua.

A linguagem é um sistema simbólico utilizado por todos os grupos humanos, serve para mediar pensamento e ação. Os estudos de Vygotsky (1999), afirmam que a função planejada da fala serve para originar as diversas funções psicológicas superiores: memória, atenção voluntária, formação de conceitos, e outras. A linguagem para ele significa um salto qualitativo na evolução da espécie. Afirma que o conhecimento se constrói de forma intersubjetiva entre as pessoas e de forma intersubjetiva no interior das pessoas. Portanto a linguagem enquanto instrumento regulador das relações sociais, não pode, de forma alguma, ser analisada fora de contexto.

\section{4.-Produção oral.}

Saussure (1993). F. Saussure estabeleceu a distinção entre "língua" e "fala" para que o paciente possa reconhecer um signo como tal e atribuir-lhe seu designado correspondente. É necessário que previamente possa apoiar-se, por um lado, nas representações psíquicas (ou significantes) dos "sons" concretos e, por outro, nas representações psíquicas (ou significados) dos referentes também concretos com os quais se relacionam esses sons. Os "signos" psíquicos, no sentido saussuriano do termo, serão constituídos, portanto, pela união dos "significantes" (ou imagem acústica dos sons) e dos "significados" (ou conceitos do referente). A oposição de dois signos complementares determina, por sua vez, uma "estrutura" ou "código". 0 estudo específico da relação lateral que se estabelece entre os significantes ou entre os significados será denominado por Saussure de "valor".

O usuário poderá estabelecer relações semiológicas corretas entre "sinais" e "mensagens" se tiver previamente formado de maneira correta as classes significantes e significadas correspondentes. Quando o usuário funciona como emissor e transmite uma mensagem por meio de um sinal, faz um "incoding", uma codagem ou codificação. Quando funciona como receptor, recebe um sinal e dele deduz uma mensagem, faz um "decoding", uma decodagem ou decodificação. As mensagens inconscientes, por exemplo, seriam essas auto mensagens que o sujeito codifica por si mesmo e que depois não sabe mais decodificar. Dentro dessa perspectiva, o psicanalista trabalha a título de intérprete entre 0 inconsciente, emissor que transmite em cifra, e o pré-consciente, receptor que não pode descrever essa cifra sob pena de experimentar desprazer.

Na patologia da comunicação do paciente psicanalítico, vemos fenômenos de codificação ou de decodificação patológicas ligadas a uma delimitação incorreta de 
classes significantes e de classes significadas; o que tem como consequência uma pragmática incorreta da comunicação. O paciente psicanalítico se põe em comunicação patológica, de um ponto de vista pragmático, com seus objetos na transferência, com seu analista, na medida em que as classes significantes de seu código informativo (equivalentes, às representações de palavras segundo Freud) e as classes significadas desse mesmo código (ou representações das coisas).

\section{5.- Produção escrita.}

A escrita é uma invenção recente, historicamente falando, afirmam Grabe e Kaplan (1996, p. 5-6). Os autores analisam que, comparada à fala que está ligada a toda a história da humanidade, a escrita foi documentada há menos de 6000 anos, e acrescentam que, embora a linguística aceite que certos aspectos da linguagem falada podem ser biologicamente determinados, o mesmo não pode ser dito sobre a escrita. Os autores ressaltam que, enquanto, normalmente, todo povo desenvolvido aprende a falar em língua materna, talvez metade da população não saiba ler ou escrever. Na opinião dos autores, isso chama a atenção para um significante contraste no desenvolvimento das habilidades da escrita e da fala.

Vygotsky (1939-1970, p. 99-107) também contempla a diferença entre a linguagem oral e escrita, assegurando que a escrita é uma forma de comunicação sem um interlocutor imediato, ou seja, direcionada a uma pessoa ausente ou imaginária ou a ninguém em particular, para a qual o escritor necessita criar a situação para representá-la. Tanto a visão de Vygostky a respeito da escrita como uma das formas mais elaboradas da linguagem que reflete nosso processo mental, quanto à de Grabe e Kaplan (1996) de que a escrita é uma tecnologia que necessita ser trabalhada e exercitada, nos faz perceber a complexidade existente no ato da escrita, fato que é merecedor de um olhar mais cuidadoso.

Ao se produzir um texto, o autor precisa ter internalizado vários conceitos, pois precisa saber o que dizer e como fazer, tornando esta produção significativa. Tornar o aluno experiente no uso da produção escrita é necessário inseri-lo em diversas produções de textos contextualizados com ambiente o qual está inserido. Para propiciar aos alunos o domínio no campo da escrita, é fazer que essa língua, a que usamos de fato, invada a escola por meio de atividades que desenvolva as habilidades necessárias para a formação do seu aprendizado.

\section{6.-Ensino de língua materna.}

No Brasil, o ensino da língua materna descortina em meados do século XIX com as reformas Pombalinas que introduzem nas escolas 0 ensino do português, 0 estudo da gramática portuguesa e a retórica, afinal neste momento linguagem era entendida como expressão do pensamento. Inicialmente, o ensino da gramática da língua portuguesa tinha como objetivo 0 aprendizado da gramática latina. Entretanto, à medida que 0 latim foi perdendo o seu valor, já no século XX, a gramática portuguesa foi ganhando autonomia e fortalecendo como área de conhecimento, mas 
desconsiderando a "língua brasileira". Assim, subsidiada por uma concepção de língua saussuriana - exterior ao indivíduo desenvolveu um modelo de ensino dirigido às camadas privilegiadas cujo objetivo era conhecer o sistema linguístico. Vale ressaltar que os estudos de Saussure editados pelos seus alunos em 1916 contemplam a língua como um fato social e trata o sistema linguístico como um sistema estruturado; a estrutura linguística é uma representação coletiva que tem poder coercitivo sobre o falante Matencio (1994).

Matencio (1994) a língua materna é inata ao ser humano e o falante a desenvolve através da relação com o meio. Língua materna seria então aquela que 0 falante domina. "Ao ensinarmos Língua Materna faz-se necessário questionarmos para quem e porque estamos ensinando essa língua. Outra questão importante no processo é a maneira que o professor concebe a linguagem e a língua (Geraldi, 1991)." Sabe-se que a pratica do professor pode alterar muito a estrutura do trabalho com língua em termos de ensino, dependendo da visão deste, poderemos ter uma pratica reflexiva ou tradicional. Neste sentido Magda Soares (1994, p. 77) diz "é que 0 ensino de língua materna, entre nós, vincula-se a uma pedagogia conservadora, que vê a escola como instituição independente das condições sociais e econômicas, espaço de neutralidade, de que estariam ausentes os antagonismos e as contradições de uma sociedade dividida em classe".

É preciso entender que uma criança que entra na escola pela primeira vez aos 6 anos idade já trilhou um longo caminho linguístico, já provou no dia a dia um conhecimento e uma habilidade linguística muito desenvolvida. Portanto subentende que o objetivo do ensino de língua materna consiste em desenvolver a competência comunicativa do falante, para que possa empregá-lo adequadamente em diversas situações de uso, Fonseca e Fonseca (1997, p. 82). A competência a gramatical ou linguística e textual. Quando falamos de competência gramatical ou linguística referimos a capacidade que 0 usuário da língua tem de construir inúmeras sequências linguísticas que nesse caso são consideradas gramaticais devido não se estabelecer um julgamento de valor normativo em verificar se a sequência da frase é admissível, aceitável como construção da língua. Chomsky denomina essa competência de "criatividade linguística", então é a capacidade que o falante tem internalizada de criar em contato com seu meio ambiente cultural um número infinito de frases gramaticais.

\section{7.-Metodologia do ensino de língua portuguesa.}

Nas premissas do estudo de Bakhtin (1986) afirma que se faz necessário fazer uma revisão de novas metodologias e prática de ensino. Nesse sentido, o que se pondera aqui é uma tentativa de refletir sobre os problemas do ensino de Língua Portuguesa. Freire (1981) verificou que a permanência de reformulação nos parâmetros de ensino é necessário, uma vez que se perceba a impossibilidade e a normatização de métodos de ensino, distanciando-se da realidade sociocultural do educando como agente principal na aquisição e edificação de conhecimento teórico-prático. Conforme destaca Travaglia (1997), o principal objetivo do ensino de língua materna nas 
escolas de Ensino Fundamental e Médio é desenvolver a competência comunicativa dos usuários da língua, onde para isso é necessário abrir a escola à pluralidade dos discursos, ou seja, à variação linguística.

Nesse mesmo sentido o Parâmetro Curricular Nacional, de (1998), de língua portuguesa, destaca que o objetivo é desenvolver no educando o domínio da expressão oral e escrita em situações de uso público da linguagem, levando em conta a situação de produção social e material do texto (lugar social do locutor em relação ao destinatário, bem como seu lugar social; finalidade ou intenção do autor; tempo e lugar material da produção e do suporte) e selecionar, a partir disso, os gêneros adequados para a produção do texto, operando sobre as dimensões pragmática, semântica e gramatical. É preciso pensar que a metodologia não é um processo de etapas fácil quando se trata de captar e analisar as características dos vários métodos disponíveis para conduzir a Língua que falamos.

\section{3.-Metodologia.}

Verificou-se os procedimentos para que representassem o percurso cujo objetivo é a produção de novos conhecimentos com um traçado planejado para a concretização dos objetivos pretendidos. 0 enfoque metodológico foi o Quali-quantitativo do tipo Descritivo a qual descreve os fatos e fenômenos Gil (2007) tendo como um dos objetivos Analisar a prática docente do professor de Língua Materna em relação à aquisição da competência comunicativa na Escola agrícola Municipal "Dep. Hitler Sansão".

Segundo Sampieri (2006) A investigação quantitativa é aquela que recolhe e analisa dados quantitativos sobre as variáveis. A investigação qualitativa evita a quantificação. Os investigadores qualitativos fazem registros narrativos dos fenômenos, que são estudados mediante técnicas como a observação participante e as entrevistas, justificando assim o enfoque quali-quantitativo. As metodologias de pesquisa qualitativa são aquelas capazes de incorporar a questão do significado e da intencionalidade como inerentes aos atos, as relações e as estruturas sócias, sendo estas últimas tomadas, tanto no seu advento quanto na sua transformação, como construções humanas Minayo (1992).

\section{4.-Discussão dos resultados.}

Neste elencamos algumas questões da pesquisa qualitativa para as análise quanto os objetivos da disciplina, a forma de trabalhar, as variações linguísticas e a visão enquanto a gramática no ensino.

\begin{tabular}{|l|l|}
\hline Questões & Respostas \\
\hline № 1: & $\begin{array}{l}\text { P1- É fazer com que o aluno consiga entender as coisas a sua volta, através da } \\
\text { leitura, da escrita, é bonito se falar corretamente. Então, pra mim, um dos } \\
\text { objetivos da língua portuguesa é saber se comunicar, produzir textos coesos, } \\
\text { interpretar e ler.P2- O principal é o bom uso da língua. Hoje não se objetiva que o } \\
\text { Os }\end{array}$ \\
objetivos domine a norma padrão, mas que ele saiba dominar a língua e possa usar
\end{tabular}




\begin{tabular}{|c|c|}
\hline $\begin{array}{l}\text { da } \\
\text { disciplina } \\
\text { de língua } \\
\text { portuguesa }\end{array}$ & $\begin{array}{l}\text { em qualquer área ou situação. P3- É fazer com que as pessoas se comuniquem, } \\
\text { de preferência sem muitos erros, onde ele utilize a linguagem de forma fluente, } \\
\text { para que o aluno possa ter contatos com diferentes tipos de pessoas as quais } \\
\text { utilizem várias maneiras de comunicação. P4- Acredito que é muito simples, que } \\
\text { nossos alunos possam expressar-se utilizando a norma culta. É direcionar, fazer } \\
\text { com que o aluno saiba discernir o certo do errado, norma culta da norma } \\
\text { coloquial. P5- É que ele domine a língua padrão, que ele se comunique, que ele } \\
\text { saiba a língua formal, mas nem por isso menosprezar a linguagem coloquial. Que } \\
\text { o estudo da língua portuguesa sirva de instrumento pra ele no seu dia-a-dia. }\end{array}$ \\
\hline $\begin{array}{l}\text { A forma de } \\
\text { trabalhar a } \\
\text { disciplina } \\
\text { de língua } \\
\text { portuguesa } \\
\text { contextuali } \\
\text { zando } \\
\text { levando em } \\
\text { conta a } \\
\text { realidade } \\
\text { do aluno }\end{array}$ & $\begin{array}{l}\text { P1- Trabalho sim, quando no início do ano letivo temos o período de sondagem } \\
\text { para verificar como os alunos se encontram e fazermos o planejamento anual da } \\
\text { disciplina, procuro abordar através da produção de texto onde abordamos o } \\
\text { contexto de nossos alunos. P2- Sim, porque temos que abordá-la de forma } \\
\text { contextualizada devido a diferença que existe em nossa clientela e para que todos } \\
\text { os alunos possam alcançar os objetivos da disciplina. P3- Acredito que tenho } \\
\text { trabalhado os conteúdos da disciplina de maneira contextualizada, pois procuro } \\
\text { proporcionar aos meus alunos atividades que os envolvam ativamente, } \\
\text { participando de forma entusiástica, abordando situações de sua realidade. P4- } \\
\text { Temos nos parâmetros nacionais de língua portuguesa toda a orientação } \\
\text { necessária para fazermos o nosso planejamento anual da disciplina e o mesmo } \\
\text { traz que devemos trabalhar os conteúdos de forma contextualizada, mas não } \\
\text { prepara o professor para trabalhar efetivamente a contextualização, fazendo com } \\
\text { que trabalhamos os conteúdos da maneira que sabemos. P5- A prática } \\
\text { metodológica realmente assumida é aquela que proporcione ao aluno aprender o } \\
\text { conteúdo seja de maneira tradicional ou contextualizada, pois o que acontece é } \\
\text { que se o aluno não aprender os conteúdos da disciplina não vai conseguir sair } \\
\text { bem quando for fazer o vestibular, ficando fora da tão sonhada formação } \\
\text { universitária. }\end{array}$ \\
\hline $\begin{array}{l}\text { O } \\
\text { desenvolvi } \\
\text { mento da } \\
\text { aprendizag } \\
\text { em através } \\
\text { da variação } \\
\text { linguística } \\
\text { em sala de } \\
\text { aula }\end{array}$ & $\begin{array}{l}\text { P1- A variação linguística tem que ser trabalhada, é importante que o aluno } \\
\text { perceba o que é norma culta e o que não é, explicando para eles que a fala é } \\
\text { diferente da escrita e que no Brasil existem muitos dialetos. P2- Ao trabalhar a } \\
\text { gramática inserida em texto, existe a preocupação de se trabalhar a questão da } \\
\text { abordagem linguística principalmente da variedade existente da língua. P3- } \\
\text { Abordo a variação linguística quando os alunos vão fazer uma entrevista para um } \\
\text { trabalho da disciplina. Mas a variação linguística já está sendo contemplada no } \\
\text { livro didático. P4- Sim, pois trabalho muito com textos regionalistas e os alunos } \\
\text { vão conhecendo a variedade linguística que existe em nosso país. P5- No } \\
\text { planejamento da disciplina anual coloco que irei trabalhar a variação linguística, } \\
\text { pois hoje esse assunto e abordado nos parâmetros curriculares nacional de língua } \\
\text { portuguesa, portanto trabalho a questão dialetal com meus alunos. }\end{array}$ \\
\hline
\end{tabular}


\begin{tabular}{|l|l|}
\hline$N^{0} 4:$ & $\begin{array}{l}\text { P1- É o conteúdo mais complexo, eu não trabalho muito não, são muitas regras e } \\
\text { os alunos não conseguem aprender quase nada. Dou mais produção de texto e } \\
\text { interpretação de texto. P2- Os alunos antigamente tinham que conhecer a }\end{array}$ \\
$\begin{array}{l}\text { A visão } \\
\text { docente } \\
\text { quanto o } \\
\text { ensino da } \\
\text { gramática. }\end{array}$ & $\begin{array}{l}\text { aluna das palavras, análise morfológica, análise sintática, etc; o aluno então } \\
\text { muitos dos aluanos, dificuldades e as leis mudaram e a gente não pode cobrar } \\
\text { gramática da língua portuguesa não é tão cobrado como antigamente. Por que o } \\
\text { que o aluno precisa saber é ler, interpretar, se expressar de maneira clara e }\end{array}$ \\
& $\begin{array}{l}\text { objetiva. P4- Com a gramática intertextual digo a que o aluno já tem internalizada, } \\
\text { percebo que a gramática normativa ficou já não é mais cobrada, pois temos que } \\
\text { trabalhar de forma contextualizada e muitas vezes não estamos preparados e o } \\
\text { aluno sai despreparado. P5- Ensinar gramática é necessário, a sua importância } \\
\text { está ligada a partir do momento que o aluno precisa utilizar na pratica o que é } \\
\text { exigido nos vestibulares e concursos. Por isso devemos fazer do ensino da } \\
\text { gramática algo mais atrativo para nossos alunos. }\end{array}$
\end{tabular}

Fonte a própria pesquisa.

Neste contexto a temática sobre a prática no processo ensino aprendizagem, sobre as estratégias utilizadas pelos docentes no ensino de língua portuguesa, são as seguintes: três professores disseram que procuram utilizar atividades diversificadas, mas disseram que os alunos não gostam de participarem, por isso fazem uso de uma metodologia tradicional e outros dois procuram tornar as aulas interessantes, fazendo com que os alunos participem, mas o ensino dos mesmos fica centralizado mais na questão textual.

Apesar dessa realidade notou-se que houve mudanças em relação ao ensino de língua portuguesa, porem a passos lentos, ao entrevistarmos os professores da disciplina de língua portuguesa dessa escola, percebemos que adotam prática pedagógica diferente. Alguns evidenciam mais o ensino da gramática normativa, outros o ensino com a realidade do educando, procurando tornar assim, o ensino de língua portuguesa significativo para os mesmos.

Tais mudanças ficaram evidentes quando os alunos distinguem entre fala e escrita. 0 contato com diversos tipos de textos significativos faz com que 0 aluno perceba no seu dia a dia que não existe uma só forma de expressão. Quando o professor respeita a individualidade deixando que eles escolham a maneira como vão se expressar, fazem com que os mesmos se sintam capazes de produzir seus textos de sua maneira. 


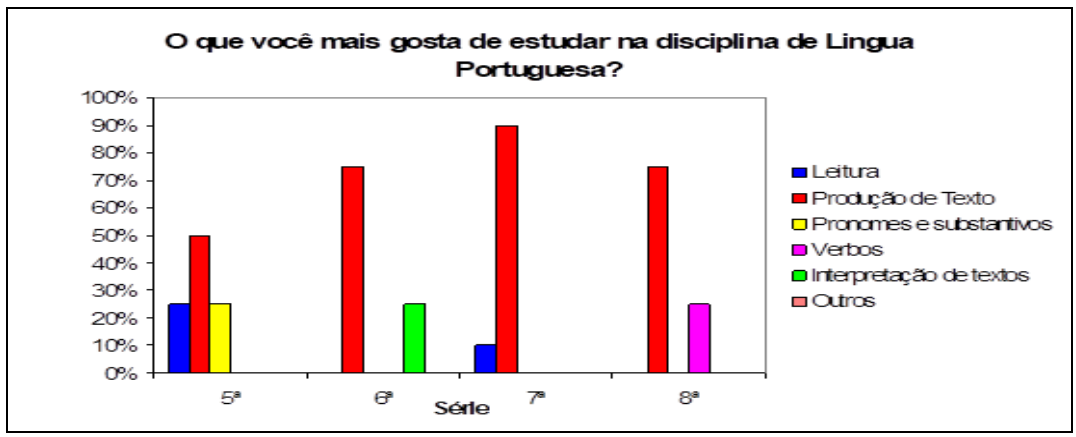

Fonte: A própria pesquisa.

Conforme gráfico a cima: As turmas de $5^{\mathrm{a}}, 6^{\mathrm{a}}, 7^{\mathrm{a}}$ e $8^{\mathrm{a}}$ destacam que 0 gosto maior que tem para estudar é a produção de texto seguido da leitura, na $5^{a}$ e na $7^{a}$ série.

Assim sendo, a produção textual a melhor atividade, considerando a gramática como a atividade mais dificuldades, isso pode estar interligado ao fato de que os conteúdos que são trabalhados dão um enfoque maior à gramática, ficando o ensino da língua restrito a mera decodificação de regras gramaticais, isso pode estar vinculado a uma concepção onde o aluno deva conhecer e dominar a norma culta para com isso produzir um texto.

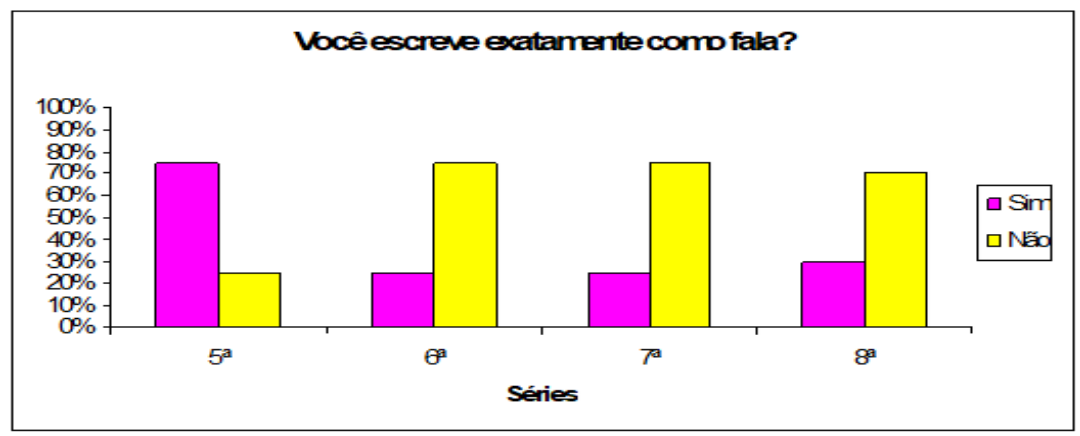

Fonte: A própria pesquisa.

Segundo gráfico a cima: Os alunos da $6^{a}, 7^{a}$, e $8^{a}$ colocam que não escrevem como falam, estes já diferenciam o falar e o escrever da língua materna com a língua formal. Já os alunos da $5^{\mathrm{a}}$ série ainda continuam escrevendo do mesmo jeito que falam (não se apropriaram ainda da linguagem formal. Ao abordar as concepções de gramática e língua materna percebe-se que a escola enquanto instituição pode ser transformadora de uma realidade, como também pode ser apenas reprodutora da mesma realidade. 


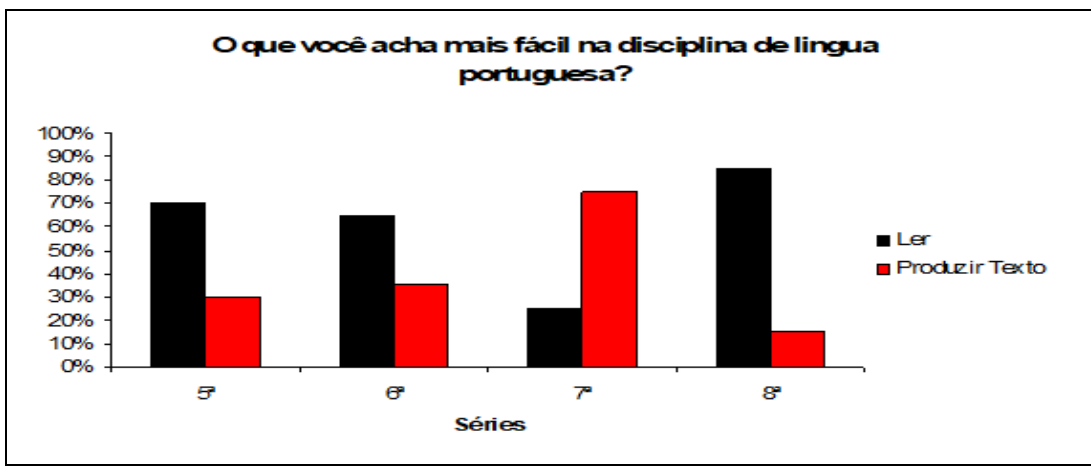

Fonte: A própria pesquisa.

Conforme o gráfico: A maioria dos alunos da $5^{a}, 6^{a}$ e $8^{a}$ série responderam que o que acham mais fácil a leitura na disciplina de Língua Portuguesa, já os alunos da $7^{a}$ a maioria diz que é mais fácil produzir textos. Pode-se dizer que o verdadeiro papel do professor de língua portuguesa não é fazer com que os falantes nativos de português, adquiram a língua materna através da memorização e mecanização de conceitos e regras normativas como se fosse uma língua estrangeira, mas que desenvolva a sua capacidade linguística e sua competência comunicativa por meio de atividades que priorize as diversidades textuais existentes em nosso meio social, para que 0 aluno possa desenvolver capacidades textuais mais complexas.

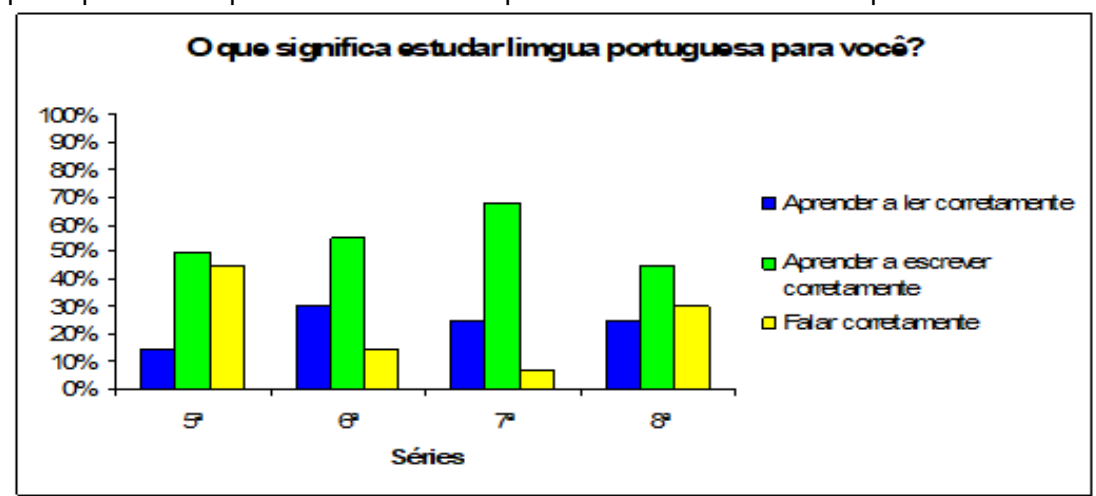

Fonte: A própria pesquisa.

Conforme gráfico a cima: As turmas de $5^{a}, 6^{a}, 7^{a}$ e $8^{a}$ colocam como significado principal da língua portuguesa é aprender a escrever corretamente, variando 0 segundo significado conforme as turmas em aprender a ler corretamente e falar corretamente. Desde modo, ideia de escrever e falar corretamente já está empregada no aluno desde as séries iniciais quando o professor evidência a linguagem formal principalmente na alfabetização, fazendo com que 0 aluno desconsidere sua linguagem de uso e tente dominar a língua padrão. Percebe-se que 0 aluno só será capaz de superar a essas dificuldades no momento em que a escola começar a se preocupar com o ensino voltado para o aluno, contextualizando 
a gramática e a desmistificando-a, deixando claro que a visão sobre o ensino da disciplina de língua portuguesa está mudando deixando de ser só gramaticista.

\section{5.-Conclusão.}

A pesquisa comprovou os objetivos e hipóteses levantadas, pois a competência comunicativa não está sendo desenvolvida de acordo com a prática adotada pelo professor de língua portuguesa, pois, os mesmos adotam uma prática voltada mais para um ensino normativo. No caso especifico do ensino de língua materna julga-se relevante a orientação do professor do ensino fundamental o apego às classificações morfológicas e as análises sintáticas, levam unicamente 0 aluno a não gostar do ensino de língua materna, pois eles não veem utilidade significativa naquilo que estão aprendendo.

Ainda, interessante demonstrar ao aluno as diferentes variedades linguísticas e que ele possa se apropriar de cada uma dessas diferentes variedades linguísticas, para utilizá-la nas diferentes situações de uso, é o mais indicado, porém não devemos deixar de esclarecer ao mesmo a importância de se conhecer a norma padrão já que é a variedade exigida no mercado de trabalho e nas situações oficiais de uso do país.

Contudo, entender que a língua materna é primordial para que possamos interagir 0 aluno ao processo de compreensão da gramática e participação no processo aprendizagem, se faz necessário abordarmos conteúdos diversificados possibilitando o desenvolvimento dos mesmos, com isso o professor estará efetivamente contribuindo para que seu aluno possa compreender as variedades linguísticas existentes e proporcionando condição para que escolha por esta ou aquela forma de aquisição do conhecimento, a qual ele se identifique mais, de acordo com a situação que esteja inserido e com o seu contexto sociocultural, desenvolvendo assim a competência comunicativa.

Enfim, a escola por sua vez se encontra muito falha nesse sentido, desde as séries iniciais coloca 0 aluno em frequente contato com textos fragmentados fazendo com que ele reproduza sentenças gramaticais pequenas, constituídas apenas de coordenação, o uso de conectivos fica comprometido devido à criança não os conhecer e consequentemente não saber como empregá-los, tornando-se um mero reprodutor de textos mal elaborados.

\section{6.-Referências.}

Almeida, M.J. (1994). Imagens e Sons. A Nova Cultura Oral. São Paulo: Cortez.

Bakhtin, M.M.(1997). Estética da Criação Verbal. São Paulo: Martins Fontes.

Bakhtin, M. (1997). Os Gêneros do Discurso. In: Estética da Criação Verbal São Paulo: Martins Fontes. 
Charolles, M. (1997). Donnés et modélisation em grammaire de texto. Refléxiones à partir del problema de la coherencia discursive. Madrid. Langue e discourso, cohier v.34. Mar, p.75-97.

Faraco, C.A., Tezza, C. (1992). Prática de Texto; língua para estudantes universitários. São Paulo: Vozes.

Freire, P. (2011). Pedagogia da Autonomia: Saberes necessários à pratica educativa. $43^{a}$ Ed., São Paulo: Paz e Terra.

Fonseca, I., Fonseca, J. (1997). Praguimática. Linguística e ensino de português. Coimbra: Almeida.

Fisher, S.R. (2006). História da Leitura. Tradução. Claúdio, F. São Paulo: Editora Unesp.

Geraldi, J.W. (2006). O Texto na Sala de Aula. $4^{\text {a }}$ Ed. São Paulo: Editora Àtica.

GIL, A.C. (2002). Como elaborar projetos de pesquisa. 4.ed. São Paulo: Atlas.

Grabe, W., Kaplan, R. B. (1996). Theory \& Practice of Writing; Longman. Educação A solução está no afeto. Gabriel C. Minas Gerais: Editora G.

Hymes, D.H. (1995). Acerca de la competencia comunicativa. In: Llovera, M. et al. Competencia comunicativa: documentos básicos en la enseñanza de lenguas extranjeras. Madrid: Edelsa.

Magda, S. (1994). O que é leitura. São Paulo: Brasiliense.

Matencio, M.L.M. (1994). Leitura, produção de textos e a escola. Campinas, São Paulo: Mercado das Letras.

Minayo, M. (2001). Fundamentos de metodologia científica. São Paulo: Atlas.

Parâmetros Curriculares Nacionais. (1998). PCNs de Língua Portuguesa. Brasília: MEC.

Possenti, S. (1997). Por que (não) Ensinar Gramática na Escola. Campinas: Mercado de Letras.

Santos G.I. (1999). Lingüística aplicada a la enseñanza-aprendizaje del español como lengua extranjera. Madri: Arco Libros.

Sausurre, F.D. (1995). Curso de Linguística Geral. Paraná: Ed Cultrix.

Sampiere, H. R. (2006). Metodologia de la investigación. México: McGraw-Hill Interamericana.

Travaglia, L.C. (1997). Gramatica e Interpretação; uma proposta para o ensino de gramática no $1^{\circ}$ e $2^{\circ}$ graus. $2^{a}$ Ed. São Paulo: Cortez. 
Revista Internacional de Apoyo a la Inclusión, Logopedia, Sociedad y Multiculturalidad. Volumen 4, Número 1, Enero 2018, ISSN: 2387-0907, Dep. Legal: J-67-2015

http://riai.jimdo.com/

Vygotsky, L.S. (1999). Aprendizado e Desenvolvimento, um processo sócio histórico. Ed. São Paulo: Scipione.

Vygostky, L.S. (1991). Pensamento e Linguagem $3^{\text {a }}$ ed. São Paulo: Martins Fontes.

Vygotsky, L.S. (1984). A Formação social da mente. São Paulo: Martins Fontes. 